Finn Frandsen* \& Winni Johansen*

\title{
The Rhetoric of Green Hotels
}

\begin{abstract}
The last two decades have seen environmentalism become a core value in western societies. This evolution, and in particular the rise of environmental consumerism, has not only forced the marketplace to be more responsive to products and services promising environmental responsibility, but has also created new types of communication, including new text genres and a new rhetoric. The purpose of this article is to analyse the environmental rhetoric of green hotels in Denmark. The article briefly presents the differences and similarities between political and commercial green discourse and then discusses the paradoxes of green marketing as reflected in the texts of some of the most important green hotel chains and associations of green hotels in Denmark. The article devotes its analysis to select rhetorical aspects of two genres, the green hotel brochure and the green card or "towel card".
\end{abstract}

\section{Introduction}

In a novel entitled Therapy, David Lodge, the chronicler of Academia, describes how the life of a British sit-com writer breaks down at both the personal and the professional level. He divorces his wife to whom he has been married for more than 20 years, and he stops writing episodes for the popular sit-com series he has created himself and which has made him a wealthy man. In the middle of his crisis, and driven by a new interest in the Danish philosopher Søren Kierkegaard, he decides to go to Copenhagen together with his mistress Samantha. The interesting thing about this journey is not so much what happens between the two characters as it is the mistress' description of the Danish hotel standards given to a friend after her return to London:

"Have you ever been to Copenhagen? Neither had I till this weekend.

It's very nice, but just a little dull. Very clean, very quiet - hardly any

* Finn Frandsen

The Aarhus School of Business

Fuglesangs Allé 4

DK-8210 Arhus $V$
* Winni Johansen

The Aarhus School of Business

Fuglesangs Allé 4

DK-8210 Arhus V 
traffic at all compared to London. Apparently they had the very first pedestrianized shopping precinct in Europe. It seems to sum the Danes up, somehow. They're terribly green and energy-conscious. We stayed at a luxury hotel but the heat was turned down to a point that was almost uncomfortable, and in the room there was a little card asking you to help conserve the earth's resources by cutting down on unnecessary laundry. The card is red on one side and green on the other, and if you leave its green side up they only change your sheets every third day, and they don't change the towels at all unless you leave them on the bathroom floor. Which is all very sensible and responsible but just a teeny bit of a downer. I mean, I'm as green as the next woman at home, for instance I always buy my shampoo in biodegradable bottles, but one of the pleasures of staying in a luxury hotel is sleeping in crisp new sheets every night and using a fresh towel every time you take a shower. I'm afraid I left my card red side up all through the weekend and avoided the chambermaid's eye if I met her in the corridor' (Lodge 1995: 183184).

Today, more than five years after the publication of Lodge's novel, nobody will anymore be surprised by finding green brochures, leaflets, cards or stickers in Scandinavian hotels trying to create an environmentallyfriendly corporate image and asking the hotel guests to separate their waste in small containers or requesting them to use the towels more than once in order to protect nature.

Contrary to the environmental rhetoric of political parties or movements that has already been the object of several studies, the green discourse of private companies has only very rarely been subjected to analysis. The present article seeks to fill this gap by analysing the environmental rhetoric of green hotels in Denmark. On the basis of a large corpus of texts from Danish hotels, we will examine how they attempt to create a green image and how they try to persuade their guests to protect nature during their stay without disappointing traditional expectations of a certain luxury. We define rhetoric very broadly as goal-oriented communication and supplement the classical battery of rhetorical concepts and methods by bringing in approaches from new linguistic disciplines such as genre analysis, text semantics and politeness theory.

The article is divided into five main sections. The first section describes how the "greening" of western societies has given rise to new types of communication that can be divided into political and commercial green discourse. The second section studies the paradoxes of green marketing: 
how is it possible to sell products to an "anti-market market"? The new green associations of hotels and hotel chains whose rhetoric we are studying are described in the third section, which also outlines our text corpus. Finally, the fourth and fifth sections analyse select aspects of the rhetoric in two new genres: the green hotel brochure and the green card (or "towel card").

\section{Green Discourses}

The last two or three decades have seen an evolution in the US and in many European (especially Scandinavian) countries that social researchers from different schools of thought have tried to capture with labels like "ecological enlightenment" (Beck 1989), "the nature/eco epoch" (Jakobsen 1998) or "greening" (Harrison 1994). In this process environment has surfaced as a societal value affecting the political life and the everyday life of all citizens and new types of communication have developed, including new text genres and a new rhetoric. This paper will focus on two new types of green discourse (see Figure 1) assuming that each of these two discourses is manifested in specific oral and/or written texts linked to the discourses by specific genre conventions (Rastier 1989: 39-49).

The first discourse is the political green discourse. It comprises every type of argumentative contribution, whether direct or indirect, to the ongoing debate on environment, pollution and animal welfare in society, from literary texts like Henry David Thoreau's novel Walden, or the Life in the Woods or an essay like Al Gore's Save the Planet to programmes, manifests, posters or mailings from green parties or movements like for example Green Peace or Friends of the Earth. The texts in which the political green discourse is manifested have already been the object of several rhetorical analyses, often departing from the social constructivist view that nature or environment does not exist in the objective sense, ie detached from the words we use talking about "nature" and "environment". The overall goal of the analysis of the environmental rhetoric is a political one. It is not just a matter of "pointing out the persuasive moments" (Aristotle), but also a question of helping the citizen participate in public debates considered indispensable for the very existence of democracy. Killingsworth \& Palmer (1992), Herndl \& Brown (1996), Harré, Brockmeier \& Mühlhäusler (1999) together with DeLuca (1999) 
all provide examples of the rhetorical study of the political green discourse.

Killingsworth and Palmer talk about ecospeak which they define as "the patterns of rhetoric typically used in written discourse on environmental politics" (Killingsworh and Palmer 1992: 1), whereas Harré, Brockmeier and Mühlhäusler prefer to talk about greenspeak which they define as "the loose cluster of dialects we could call the 'language of environmentalism' itself: Greenspeak, the whole gamut of linguistic means employed in raising awareness of environmental issues in a range of discourses both radical and conservative" (Harré, Brockmeier \& Mühlhäusler 1999: 2).

Inspired by Ogden and Richards' rhetorical triangle from The Meaning of Meaning (1923), Killingsworth and Palmer's "Continuum of Perspectives on Nature" and the classical rhetorical distinction between types of persuasion (logos, ethos and pathos), Herndl and Brown have established a rhetorical model for environmental discourse. They distinguish between a) an anthropocentric scientific discourse $(\log o s)$ that sees nature as an object of knowledge; b) an ethnocentric regulatory discourse (ethos) that perceives nature as a resource; and c) an ecocentric poetic discourse (pathos) defining nature as spirit. Thus, we rediscover the philosophical distinction between what is true, what is good and what is beautiful, or between science, politics and art.

Figure 1. Green discourses in western societies

THE "GREENING" OF

WESTERN SOCIETIES

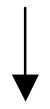

New types of communication

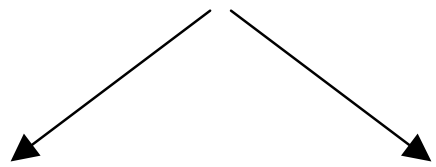

THE POLITICAL

THE COMMERCIAL

GREEN DISCOURSE GREEN DISCOURSE 
The second discourse is the commercial green discourse. It comprises all the texts produced by private companies in order to market green products or to create a green corporate image, from eco-labels, packaging texts and advertisements to company brochures, annual reports and websites. The commercial green discourse springs from the companies' alertness to the growing number of critical consumers (from the individual consumer to public institutions like schools and hospitals) who want to buy ecological products produced under environmentally-friendly conditions. Thus, "green marketing" constitutes an important sub-area within marketing (see for example Ottman 1998 or Fuller 1999 to mention just two examples from the abundant literature of manuals).

Contrary to the political discourse, the commercial discourse has only been subject of very few rhetorical studies. Sharon Livesey has proposed the label BED, ie business environmental discourse, for this kind of discourse (Livesey 1999 and 2001). The studies seen so far have been undertaken by social researchers within the field of business administration and economy departing from qualitative content analysis (see for example Carlson, Grove \& Kangun 1993, Banerjee, Gulas \& Iyer 1995 or Easterling, Kenworthy, Nemzoff \& College 1996). ${ }^{1}$

\section{The Paradoxes of Green Marketing}

The commercial green discourse has spread to nearly all branches and areas including companies forced to act in an environmentally-friendly way because their products or production methods are damaging the environment as well as companies that at first glance do not seem to harm the environment, like for example the service sector.

This trend presumably originates in today's consumer interest reaching beyond products to companies themselves, specifically their ethics and values. Consumers are becoming more concerned with such questions as: What does the company stand for? Which are the most appreciated values? And how does the company relate to its surroundings? Consumers and authorities are becoming more and more demanding of the behaviour

1 Of general, and not only rhetorical, interest is ECN (the Environmental Communication Network) which has been created in connection with the biennial conferences on communication and environment held in the USA since 1991 (www.esf.edu/ecn). 
and social responsibility of the companies, and the mass media are monitoring each of their steps, even the smallest ones. A company's reputation and image is therefore playing an ever more central role for their longterm survival, and corporate identity and corporate values are becoming important competitive parameters. The classical communication of product-related values is supplemented or replaced by an attempt to communicate certain society-related values that may contribute to the creation of a positive corporate image.

It is no longer enough just to be green "in words", you must also be green "in deeds". The "greenness" of a company may vary from limitation of water and electricity consumption in the production process to waste water treatment. Or, as it is the case in the growing number of companies wishing to be environmentally conscious all through the production chain, from the way raw materials are extracted to the production process itself and how the products can be disposed of and degraded in an environmentally-friendly way after use. Some researchers and managers even speak of an ecological organizational culture where "greening" is pervasive (Lemcke 1999).

But how can you create a green image by means of communication? Image is traditionally defined in the following way:

"An image is the set of meanings by which an object is known and through which people describe, remember and relate to it. That is, it is the net result of the interaction of a person's beliefs, ideas, feelings and impressions about an object" (Dowling 1986: 110).

A company tries to create an image, and preferably a specific positive image, through its self-presentation, ie its corporate identity (cf. van Riel 1995), but the desired and the actual image of a company may occasionally be at odds. The creation of images takes place in the mind of stakeholders, ie all the different internal and external groups who have a 'stake' in the company (shareholders, employees, customers, suppliers, the local community and even broader society). Images are created at many different levels: product class, brand, company, sector, country or user. The company does not have a single image, as images may vary from stakeholder to stakeholder.

By communicating its attempt to protect nature, to show responsibility and ecological concern, ie by communicating in a "green way", the company tries to create a green image among its stakeholders, may they 
be political consumers or partners. However, the green communication constitutes something of a paradox, because on the one hand, the company wishes to encourage the protection of nature in order to avoid waste of precious resources and over-consumption, but on the other hand the very purpose of communicating is to "sell" the company and its products, ie to increase consumption. In Stephen Brown's words:

With its anti-consumption, anti-waste, anti-exploitation outlook, the green movement represents the antithesis of all that marketing stands for, or, rather, is presumed to stand for by the community at large. [...] it is undeniable that there is something profoundly paradoxical - not to say morally questionable - about vilifying the market, adopting an antibusiness ethos and condemning over-consumption, while purveying consumables, being in business and profiting from the anti-market market (Brown 1999: 37).

A clear example of this kind of anti-market marketing is found within the hotel and tourism sector where the hotels are nowadays presenting themselves as ecologically conscious companies wishing to protect nature by "selling" smoke-free rooms, ecological food, ecological camping sites and even environmentally-friendly tours.

When trying to create a green image, the hotel often adds new values to the classical hotel values which creates a new paradox. The paradox lies in the failing agreement between words and deeds. On the one hand, the hotel would like to reduce for example the consumption of soap, water and electricity in order to protect nature, and on the other hand, it wishes to please the hotel guest paying for the luxury of a pleasant stay at a hotel. The classical values ascribed to a stay at a hotel must therefore be supplemented by green values calling for moderation in the attempt to protect nature.

It is therefore necessary for the hotels both to show green responsibility and to nourish the traditional idea of a good stay at a hotel where the hotel guests are never disappointed in their expectations of a certain luxury. In the following section we shall take a look at how Danish hotels are seeking to solve this paradox by presenting their corporate identity in a specific way through new types of communications and new genres. 


\section{Green Hotels in Denmark}

Research into the commercial green discourse, in casu the environmental communication of hotels, is sparse as mentioned above. None the less, Diamantis \& Ladkin (1999) have tried to portray the new development within this sector. They draw, among other things, attention to the creation within the tourist and hospitality industries of various private or public associations handling environmental questions on behalf of their members such as The Green Globe (www.greenglobe21.com) which in 1998 had 577 members in 107 different countries and which assists and advises its members in matters of ,green“ or environmental issues.

One of the members of The Green Globe is Danish, namely The Green Key (dengroennenoegle.dk) which was founded in 1994 and which consists of tourism organisations and members of the hospitality and restaurant industries in Denmark. The Green Key is both the name of the association and a diploma awarded to hotels, youth hostels, conference and holiday centres, camping sites and holiday houses living up to a long list of environmental requirements. The Green Key is awarded for a period of 12 months, after which it must be renewed. The awarded companies have the right to use the logo of the association which comes close to being a quality mark or a guarantee paraded by the hotels wishing to emphasize their green responsibility. Available is also a brochure translated into the most important foreign languages. The individual hotel may either stamp its own name and logo on the ready-printed brochure or just add the brochure to its own presentation materials. Today, The Green Key counts 93 members, and the number is growing steadily.

Hotel chains are also promoting their wish to contribute to the protection of nature on an individual basis, for example Best Western Denmark (www.bestwestern.dk) which has entered into partnership with the WWF (World Wildlife Fund) Denmark donating one Danish Krone to this organisation for each bed-night and receiving in return the right to advertise the partnership in its environmental communication. This type of collaboration between commercial companies and NGOs is, of course, an advantage for both parties. The WWF gets financial support, whereas Best Western Denmark can create itself a positive corporate image. A third and final category of hotel chains is seeking to create a green image without collaborating with environmental organizations like WWF, eg the Scandic Hotels whose goal is to be one of the most environmental- 
ly-friendly companies in the hotel industry and who communicate its green corporate identity promising to "return all our rooms to mother nature".

All the associations or hotel chains mentioned above are seeking to create a green image by means of new types of communication, including new text genres and a new rhetoric, as evidenced by the corpus on which our investigation is based. A total of 86 hotels participated in the study. On the basis of their texts we have established the following typology of different types of green communication (see Figure 2).

\section{Figure 2. Different types of green communication from Danish hotels}

\begin{tabular}{|c|c|}
\hline $\begin{array}{l}\text { EXTERNAL } \\
\text { COMMUNICATION }\end{array}$ & $\begin{array}{l}\text { 1. Special brochures prepared by associations of } \\
\text { green hotels (The Green Key for example) } \\
\text { 2. Special green brochures prepared by individual } \\
\text { hotels (The Scandic Hotels for example) } \\
\text { 3. The ordinary company or product brochures in } \\
\text { which the hotels can show their green corporate } \\
\text { identity or products } \\
\text { 4. "Hotel newspapers" in which the hotels show } \\
\text { their green corporate identity } \\
\text { 5. Extracts from information given to the hotel } \\
\text { guests at the reception or placed in the hotel rooms } \\
\text { 6. Cards or stickers placed on door handles, tables } \\
\text { or shelves in the hotel rooms (in particular the } \\
\text { bathrooms) } \\
\text { 7. Questionnaires including green questions } \\
\text { delivered to the hotel guests }\end{array}$ \\
\hline $\begin{array}{l}\text { EXTERNAL AND } \\
\text { INTERNAL } \\
\text { COMMUNICATION }\end{array}$ & 8. Green action plans delivered to the hotel guests \\
\hline $\begin{array}{l}\text { INTERNAL } \\
\text { COMMUNICATION }\end{array}$ & 9. Extracts from the hotel's staff manuals \\
\hline
\end{tabular}


As appears from the typology, the majority of the text genres are instances of external communication, eg the special brochures prepared either by associations of green hotels like The Geeen Key or individual hotel chains like Best Western Denmark or the Scandic Hotels. Other examples of external communication include the traditional hotel brochures or what we have chosen to label "hotel newspapers" together with questionnaires given to hotel guests and different types of cards or stickers requesting the hotel guests to use the towels more than once in order to protect nature. All these types of external communication are, of course, also read by the staff, but in order to assure coordination in their corporate communication, the hotels also communicate their green identity internally in the form of action plans and staff manuals.

\section{Green Hotel Brochures}

The first text genre within the environmental communication of green hotels analysed in this article is the special green hotel brochure. Some hotels choose to incorporate the new green aims and values in their traditional presentation material. Other hotels living up to the criteria established by The Green Key have decided to supplement the traditional material with the special green brochure issued by this association. Finally, some hotels prefer to add a special brochure they have prepared themselves. It may be argued that this last text category is the greenest of them all, because it serves the primary goal of strenghtening the hotel's green image by informing the reader about its green consciousness and behaviour. This is also what makes the green rhetoric of these texts particularly striking; and the reason why we have chosen to examine this particular text genre. We will use the genre analytic model devised by Swales (1990) and Bhatia (1993), which is based on the following four key concepts: discourse community, communicative purpose, move-structure and rhetorical strategy. See Section 6 for an analysis of the green cards (or „towel cards").

\subsection{Discourse Community and Communicative Purpose}

The discourse community served by the green hotel brochure comprises the hotels and their guests, ie business people, tourists and conference participants, etc. The communicative purpose is dual. The primary pur- 
pose is to cultivate the profile of the hotel and to create a specific, positive image among the hotel guests (responsibility regarding society and the environment). The secondary purpose is to make the guests act in an environmentally-friendly way during their stay and to convince them that their rights as guests will not be jeopardized by responding to these new initiatives.

\subsection{Move-structure}

The prototypical move-structure of the green hotel brochure unfortunately cannot be described at present because the number of texts is too small to allow analysis of the recurrence of moves. Instead, we will analyse the strategic composition of single texts, taking first as an example the special green brochure prepared by the Scandic Hotels in its first edition entitled We must all take responsibility for our common environment (symbolized by a large yellow butterfly at the frontpage). This edition was used until the year 2000 where the text was updated and supplied with a new title The EcoLogical choice - Can you think of a nicer way to care for the environment? It is a rather small brochure in colours (36 pages, $10 \times 18 \mathrm{~cm}$ ) with a Danish and English version of the same text. It tells what the Scandic Hotels are doing in order to protect nature and how the guests can support this effort. As appears from the title, you can, literally speaking, get a good conscience simply by sleeping in one of Scandic's eco-rooms which are ,97\% recyclable". Scandic explicitly defines its goal in the brochure: „Our objective is to become one of the most environmentally-friendly companies in the hotel industry and operate in accordance with the conditions of Nature".

The Scandic brochure consists of a front page and ten segments all consisting of a double page where the page to the left is a photo and the page to the right a verbal text and a matching paratext. As appears from Figure 3, which is a survey of the contents of the ten segments, the sender, ie the Scandic Hotels (and what they do in order to protect nature), is in focus, but the receiver, ie the guests, is also assigned a role. 
Figure 3. Segmentation of the Scandic brochure

\begin{tabular}{|cl|}
\hline Segment & Paratext \\
Front page & The EcoLogical choice - Can you think of a nicer way to care for the \\
& environment? \\
1. & We are continuing to make Scandic your natural choice of hotel. \\
2. & We have already come a long way in our environmental work. \\
3. & We plan to return our rooms to nature. \\
4. & We help protect the Earth's limited water resources. \\
5. & Our guests reduce soap and shampoo emissions by 25 tonnes per \\
6. & Wear. \\
7. & We need your help in our natural recycling programme. \\
8. & This is an ongoing commitment, to ensure a good future for us all. \\
9. & The Natural Step. \\
10. &
\end{tabular}

Even though we cannot make a comparative analysis of a sufficiently large number of green hotel brochures and thereby establish the prototypical features of this genre, it is still possible to analyse the tactical messages underlying this segmentation. A short analysis of the contents of all segments reveals the following structure. The individual parts are not tied to a single segment, but may appear tie in with more than a single segment or even run across the whole brochure (Figure 4).

Move 1 legitimises the address. Scandic presents the problem - that the environment suffers - and explains its part in it. In move 2, the hotel guest is requested to collaborate in protecting nature and a solution to the problem is suggested. Move 3 assures that the rights of the hotel guest will not be jeopardized, ie that the comfort will remain the same. In move 4, the quality of the ,product“, ie the environmental work done by the Scandic Hotels, is legitimised by describing the extensive environmental education of the co-workers and the local activity programmes. In move 5, the ,product“ is described in detail. The move consists of a series of parallel micro-moves each describing a select aspect: how the rooms will be „returned to mother nature“, water conservation, reduction of soap and shampoo emissions, recycling programme together with many other measures „for the sake of the environment“. In move 6, the hotel 
Figure 4. Realization of the communicative purposes (the Scandic brochure)

Move 1: To legitimise the address

Scandic Hotels is like a miniature society. Every day thousands of people live, work, eat and enjoy themselves in our hotels. Every hotel is also part of modern society; a society that continually draws on the resources of nature and the world.

Move 2: To request collaboration in order to protect nature

We must work together to try to stop this development.[...] To succeed we must all take responsibility for our shared environment. We have taken the first, natural steps and hope that you, as our guest, will help us in our efforts - for the sake of our environment and our shared future.

Move 3: To ensure that the rights of the hotel guest will not be violated

As a guest at Scandic, you will not notice any real difference. You will find the same comfortable beds and be able to enjoy the big breakfast buffet with the same appetite. [...] as you shower you will experience a comfortable flow of water, even though the amount of water you use will be several litres per minute less than that consumed with a conventional shower.

Move 4: To legitimise the quality of the ,product“" (the hotel's environmental work) We have already come a long way in our environmental work. During 1994, all of Scandic's employees attended a comprehensive training programme in environmental matters. [...] To date, we have carried out over 2,000 measures to improve our environment. The objective of each one is to reduce the strain on the environment and preserve nature's resources.

Move 5: To describe the ,product“"

We plan to return our rooms to nature. All new hotel rooms built for Scandic are recyclable.

[...] we have introduced water conserving measures in all of our hotels.

Move 6: To invite to make contact

If you have any personal thoughts on how we could improve our environment, we would be glad to hear from you.

Move 7: To legitimise and sanction the initiatives

Scandic co-operates with the officially approved environmental organisation ,The Natural Step" and is the only hotel chain to do so. [...] Scandic Hotels has been awarded several local and international prizes for its environmental work. improvements of the environmental programme. The role of the last move 
is to legitimise and sanction the initiatives presenting the collaboration with The Natural Step, a Swedish environmental organisation and the prizes and awards received by Scandic for its environmental work.

Let us take a rapid glance at another example from our corpus, namely the Best Western brochure entitled Thank you for choosing a hotel that is committed to nature conservation and the environment (and sub-titled Welcome to Best Western Denmark). It is a much smaller brochure comprising a front page and five segments. Analysis gives the following structure (Figure 5).

Figure 5. Realization of the communicative purposes (the Best Western brochure)

Move 1: To thank the hotel guest for having chosen to stay at the hotel and to protect nature

Thank you for choosing a hotel that is committed to nature conservation and the environment

Move 2: To address the hotel guest directly

Dear hotel guest

Move 3: To welcome the hotel guest (in the form of a letter)

First of all I should like to bid you welcome to our Best Western Hotel.

Move 4: To request collaboration in order to protect nature

[...] how easy it is for you to help reduce our environmental impact. [...] We can all help $[\ldots]$

Move 5: To legitimise the address

What is the problem? We all know that the global environment is suffering badly.

Move 6: To propose a solution to the problem

What is the solution? [...] We can all help [...] by saving energy whenever possible

Move 7: To ensure that the proposed solution will not reduce the comfort

We can also help save on washing powder, water, electricity and heating when we stay in hotels - without detracting from the comfort of our stay.

Move 8: To legitimise and sanction the initiatives

What is WWF Denmark? [...] Playing its part for the environment (royal testimonial and diploma by HRH Prince Henrik)

Unlike the Scandic text, this brochure carrying both the WWF logo (the giant panda) and the Best Western logo starts with thanking the hotel 
guest ,for choosing a hotel that is committed to nature conservation and the environment". This is just another way of realizing the same communicative purposes, because, here, too, the main idea is to strengthen the hotel's green image. Comparison of the structure of the two brochures reveals certain recurrent moves, ie moves 1 to 5 . This indicates that we may expect to find the same moves in corresponding brochures; a recurrency that may qualify as a thrue outline of a move-structure in the proper sense of the word.

\subsection{The Rhetoric of Green Hotel Brochures}

The last part of the analysis of the special green hotel brochures is devoted to the rhetorical strategies. The brochures being large texts comprising a large number of various verbal and non-verbal strategies, we will concentrate on a few characteristic strategies in Scandic's The EcoLogical choice brochure, namely the interaction between text and image, the staging of the sender/receiver relationship and select semantic isotopies.

\subsubsection{Visual Strategies: The Interaction Between Text and Image}

The interaction between text and image is very close. The paratexts pilot the decoding of the images that in return complete the main text. The images represent segments of the areas mentioned in the verbal segments. The front page The EcoLogical choice displays part of a hotel room. The first segment (1) We are continuing to make Scandic your natural choice of hotel consists of a photo showing a table with a mobile phone, a newspaper, a bottle of spring water illustrating what the guest typically is doing during his or her stay at the hotel: eating, drinking, talking, etc. (2) We have already come a long way in our environmental work is illustrated by a light switch, (3) We plan to return our rooms to nature by a bed fence made of wood and (4) We help protect the Earth's limited water resources by bobbles in a glass. (5) Our guests reduce soap and shampoo emission shows water on the floor of a cabinet shower, (6) We keep a clean house without polluting nature parts of cleaning materials, (7) We need your help our natural recycling programme part of a waste container and (8) This is an ongoing commitment shows parts of furniture. The Natural Step in segment 9 is illustrated with a flower, whereas the 
last segment (10) Appreciation for our environmental work is accompanied by the picture of part of a dish towel. The angle and the techniques used show that all the images serve an aesthetic function of representing the hotel and its rooms in a highly artistic way. The quality of the photos underlines the quality of Scandic's work and its green values.

\subsubsection{Verbal Strategies: Staging of the Sender/Receiver Relationship}

The invitation to share responsibility for the environment and the strengthening of the hotel's green image are realized by a rhetorical strategy alternating between an exclusive we and an inclusive we.

The inclusive we comprises both the hotel and the guests: „We must work together to try to stop this development. [...] To succeed we must all take responsibility for our shared environment [...]. For the sake of our environment and our shared future. [...]". Whereas the exclusive we is only used when talking about the sender, ie the Scandic Hotels, cf. Figure 3 and the many we's in the paratexts: ,We are [...]. We have [...]. We plan [...]. We help [...]. We keep [...]. We need [...]". The exclusive we, which is far the most frequent of the two, emphasizes Scandic's environmental measures.

The sender addresses the receiver directly with a you, in the title: "The EcoLogical choice - Can you think of a nicer way to care for the environment?", and later on in the text: ,[...] and hope that you, as our guest, will help us in our efforts. [...] As a guest at Scandic, you will not notice any real difference. You will find the same comfortable beds [...]. If you have any personal thoughts on how we could improve [...]". But in some places, the receiver is mentioned in an impersonal way, as the category ,hotel guest“, for example in the paratext in Segment 5: „Our guests reduce soap and shampoo emissions by 25 tonnes per year", apparently as a kind of variant to the frequent use of the exclusive $w e$ in the paratexts. Focus is shifting from sender to receiver. The guests still belong to the sender - „our guests“ - but now they also take an active part (at least the guests who stayed a the Scandic Hotel before the one reading the brochure for the first time). 


\subsubsection{Verbal Strategies: Staging of „Greenness“}

The "greenness" is staged by means of semantic isotopy including the words nature and nature, but with a dual meaning. Thus, they are used both with reference to nature (marked with an underlining in the examples below) and with reference to logic, to what is obvious or "natural“ (marked with italics in the examples below).

Figure 6. The dual meaning of nature and natural (semantic isotopy)

The paratexts:

We are continuing to make Scandic your natural choice of hotel.

We plan to return our rooms to nature.

We keep a clean house without polluting nature.

We need your help in our natural recycling programme.

The Natural Step.

In the main text:

For thousands of years man lived on what the earth, forests and water gave him naturally. [...] Today, we can no longer take this for granted.

$[\ldots]$ that functions in harmony with nature's own cycle.

[...] to adapt our hotels to the natural cycle

We have taken the first, natural steps [...]

$[\ldots]$ and operate in accordance with the conditions of Nature

$[\ldots]$ and preserve nature's resources.

As appears from Figure 6, the word natural is often ambiguous referring to both nature and logic. It is also interesting to note that it has become possible to „return rooms back to nature“.

Another important semantic isotopy is a dichotomy exploiting the opposition between work and leasure or obligation and pleasure. The Scandic Hotels are doing the hard environmental work while the guest is enjoying him/herself during the stay at the hotel. 
Figure 7. Dichotomy exploiting the opposition between work and leisure (semantic isotopy)

We have already come a long way in our environmental work.

[...] to contribute to our environmental care work

And, remember, we never rest on our environmental laurels. Something worth thinking about when you relax at Scandic.

You will find the same comfortable beds and be able to enjoy the big breakfast buffet with the same appetite.

But it is not just a question of making the hotel guest relax, because (s)he must be persuaded that (s)he, too, must contribute to the environmental work. But how is this possible without rejecting what has already been said? The invitation to collaborate, ie to work together to protect nature, moderates the strong work aspect by means of down-toners like comfortable, nice and easy; as already mentioned, it is possible to contribute to Scandic's environmental work just by making an „EcoLogical choice" and by sleeping at one of their hotels.

Figure 8. Examples of down-toners (the work aspect)

The EcoLogical choice - Can you think of a nicer way to care for the environment?

We want to make your stay at Scandic the nicest way to care for the environment imaginable.

[..] as you shower you will experience a comfortable flow of water, even though $[\ldots]$

We have now created a system that is both easy for our guest and beneficial to the environment.

This recovery system is a convenient way for our guest to contribute to our environmental care work.

The rhetorical strategies are used in order to impress and to persuade the receiver about the ,greenness" of Scandic, thereby creating a strong green image among the hotel guests. However, the paradox remains: at one and the same time Scandic emphasizes moderation and maintains the guest's right to enjoy the luxury traditionally associated with a stay at a 
hotel trying by reducing the gap using specific rhetorical strategies. As we will see in Section 6, these strategies are even more obvious in the green cards where the hotels must overcome the same paradox within a much smaller text.

\section{Green Cards}

The second text genre within the environmental communication of green hotels analysed is the so-called green card (or "towel card"). This genre seems to originate from the US where the green card is marketed by associations of green hotels (like the "Green" Hotels Association, www.greenhotels.com) together with a long series of other types of readyprinted cards like sheet-changing cards, "we recycle" table tents, lights out cards, environmental deck-of-cards, water-conservation table tents and guestroom newsletters. But today, the green cards have spread to hotels in many European countries, even though the distribution may vary a lot depending on differences in environmental consciousness and culturally-specific expectations to a stay at a hotel. Whereas the green cards are very common in Scandinavian hotels where they have been used for years, they are only rarely found in hotels in Southern Europe.

\subsection{Discourse Community and Communicative Purpose}

We may reasonably assume that the green cards share the same discourse community as the green hotel brochure, ie business people, tourists, participants in conferences, etc. This does not, however, imply that the green cards also serve the same communicative purpose(s) as the green hotel brochure. Indeed, both text genres have in common that they contribute to the creation of a green image, but unlike the hotel brochure the green cards seeks to exercise a direct and more specific influence on the behaviour of the hotel guests. The communicative purpose of this genre may therefore be defined as making the hotel guest decide whether (s)he wishes to use the towels once more in order to protect nature (and instructing him or her how to signal this decision). Thus, the creation of a green image is not the primary communicative purpose. Different, longterm strategic goals that have no direct dependency relationship with a specific genre may be discerned beneath the overt purpose, viz a sincere wish on part of the hotel to contribute to the protection of nature, or just 
a wish to reduce water and electricity costs by living up, in words and in deeds, to the criteria formulated by the associations of hotels. According to The Green Key, some Danish hotels have hence reduced their costs by some $25-30 \%$. "Idealism pays", as the hotel managers have begun proclaiming.

\subsection{Move-structure}

The move structure of the green cards is much more complex than we expected. We have analysed the move structure in more than 30 different green cards, of which 17 were Danish, and found that these rather small texts may contain up till six moves. The first move consists in a short invitation to care for the environment. In the second move, the hotel addresses the guest directly. The third move legitimises the invitation, most often by describing the adverse effects on the environment of unnecessary washing of towels. The fourth move consists in inviting the guest to decide whether (s)he wants to use the towels once more (and instructing him or her how to signal this decision). The fifth move again legitimises the invitation or the request, and the sixth and last move simply thanks the guest in a polite way.

Figure 9. The move structure of green cards

Move 1: To invite the hotel guest to care for the environment

Move 2: To address the hotel guest

Move 3: To legitimise the address (description of the situation)

Move 4: To request a decision (a choice) and/or to instruct on what to do

Move 5: To justify the request/the instructions

Move 6: To thank the hotel guest and/or to end politely 
We do not want to go into details with the analysis of the move structure of green cards, but the structure represented in Figure 3 is the result of an additive approach where we have collapsed all the moves represented in the cards analysed so far. In other words, the result of our analysis is not a prototypical structure; it is what you may call a maximum structure given that you only very rarely find all the six moves present at the same time. But the prototypical move structure will, of course, appear when analysing the frequency of each move (for a more profound analysis of the move structure of green cards including the frequency of each move, see Frandsen \& Johansen 2001).

\subsection{The Rhetoric of Green Cards}

Elicitation of the communicative purposes and the moves requires resort to a series of rhetorical strategies, verbal as well as non-verbal. The latter include the logo of the hotel or the hotel chain, the logo of The Green Key or WWF, eco-labels, pictures of endangered species or beautiful natural surroundings, funny drawings of a smiling sun, smiling or talking towels or male and female hotel guests showing how to place or not to place the towels. This group also comprises the use of recycled paper and the idea of placing the green card on the door handle, on the wall beside the mirror or on the rack in the bath room in such a way that the hotel guest cannot avoid reading it. The verbal strategies include for example the sender's staging of herself as the chamber-maid or as mother nature addressing the hotel guest directly and the use of specific explicit or implicit argumentation strategies. It falls outside the scope of this article to analyse all these rhetorical strategies. Instead, we have decided to focus on a single set of verbal strategies that are playing an important role in the environmental communication of (green) hotels, ie politeness strategies.

Politeness is very often used as a rhetorical strategy in green cards (and in the environmental communication of hotels as such), first of all because hotels easily risk to offend their guest when communicating in a "green" way. In order to understand why this is the case, we will have to take a closer look at linguistic politeness and the traditional expectations of a certain luxury among hotel guests.

Today, the most widespread and well-known theory on linguistic politeness is the theory elaborated by Penelope Brown and Stephen 
Levinson in Politeness (1978). Inspired by Anglo-Saxon theory on conversational maxims (Grice's "Be polite") and interactionist microsociology (Goffman's face work theory), this theory is based on the following assumptions:

1) Every individual has two faces: a negative face corresponding roughly speaking to what Goffman calls territories (see below) and a positive face corresponding to the "narcissism", the self-image, made up by the individual and presented to the surrounding world. Thus, when two individuals are interacting, no less than four faces are involved;

2) The acts performed by the individuals when interacting represent a potential threath towards one or more faces of the individuals. This is the reason why Brown and Levinson label these acts face-threatening acts (FTAs);

3) To "lose one's face" is a symbolic defeat that individuals avoid as far as possible during their interaction by engaging in verbal behaviour that seeks to protect both parties' faces during conversation (see 4). The wish to "save face" is called face want by Brown and Levinson;

4) The individuals avoid losing face by engaging in what Goffman calls face work; Brown and Levinson prefer to speak about politeness strategies. There are positive politeness strategies (like showing interest in the receiver, seeking consensus, offering and promising) and negative politeness strategies (like using conventionally indirect forms of expression, using impersonal turns of speech, apologizing). Exactly which type of politeness strategy is to be used in a specific situation depends on three factors: 1) the extent of the threat (how serious is the FTA?), 2) the social distance between the individuals (a symmetrical/asymmetrical relationship), and 3 ) the power relationship between them (an asymmetrical relationship). The basic idea is that, in principle, the degree of politeness will increase directly proportional to the extent of the threat, the distance and the power relationship.

Brown and Levinson's theory has been criticised and further developed by a long series of researchers, among others the French linguist Catherine Kerbrat-Orecchioni who pointed to the fact that Brown and Levinson have a far to pessimistic or even "paranoiac" idea of the interaction between human beings as consisting exclusively of face-threatening acts. She has also, together with others, pointed out that Brown and Levinson's concepts of positivity and negativity are ambiguous (Kerbrat-Orecchioni 
1992: 176-180, 1996: 53-54). Therefore, Kerbrat-Orecchioni suggests a reformulation of the model introducing the concept of face-flattering acts (FFAs) and specifying that negative politeness is "abstentionistic" or "compensatory", whereas positive politeness is "productionistic". When applied to the interaction between hotels and hotel guest, we get the following model (see Figure 10). ${ }^{2}$

In this scenario "green" communication may easily be perceived as verbal action threatening territories or faces. But what does the territory or the face of a hotel guest look like? In his book Relations in Public (1972), the American micro-sociologist Erwing Goffman has sought to apply the concept of territory belonging to ethnology to the study of human interaction. He makes a distinction between three types of territory: 1) "fixed" territories like for example a house or a flat, 2) situational territories like for example a table in a restaurant or a bench in a public park and 3) "ego-centric" territories like for example a woman's handbag. In Goffman's efforts to apply the concept of territory, this trichotomy is immediately followed by a much more complex typology going from spatial territories (like the proxemic sphere) to territories that are not spatial, but nevertheless function as such (like information one has or one's turn during a conversation).

Goffman himself notices that his trichotomy is only of limited validity in so far as many territories overlap, and he offers the status of a hotel room as an example of a territory: a hotel room is a situational territory, but in its function it reminds of a house, ie a fixed territory. To be more precise, this territory, which is at the same time both situational and fixed, consists of the right to stay in a particular place (a hotel and a hotel room belonging to a specific category) in a particular period of time (a number of bed-nights) and with a particular comfort to which culturally-specific expectations of a certain luxury are tied (room service, minibar, telephone, etc.). The hotel guest gets "offended" or feels that he or she is treated in an "impolite" manner, when the hotel in words and deeds threatens his territory or face: when the guest gets another room or a less comfortable room than the one (s)he has booked, when the guest gets a more modest breakfast than expected... or when the

2 We would like to stress that in this article we are only focussing on the receiveroriented politeness strategies and that consequently the territories or the faces of the hotel will not be described. 
guest meets a green card requesting him or her to use the towels once again - in order to protect the environment. Just as you had looked forward to the luxury of taking an extra long hot shower using all the fresh towels you want to!

Figure 10. Model for the analysis of linguistic politeness in green cards

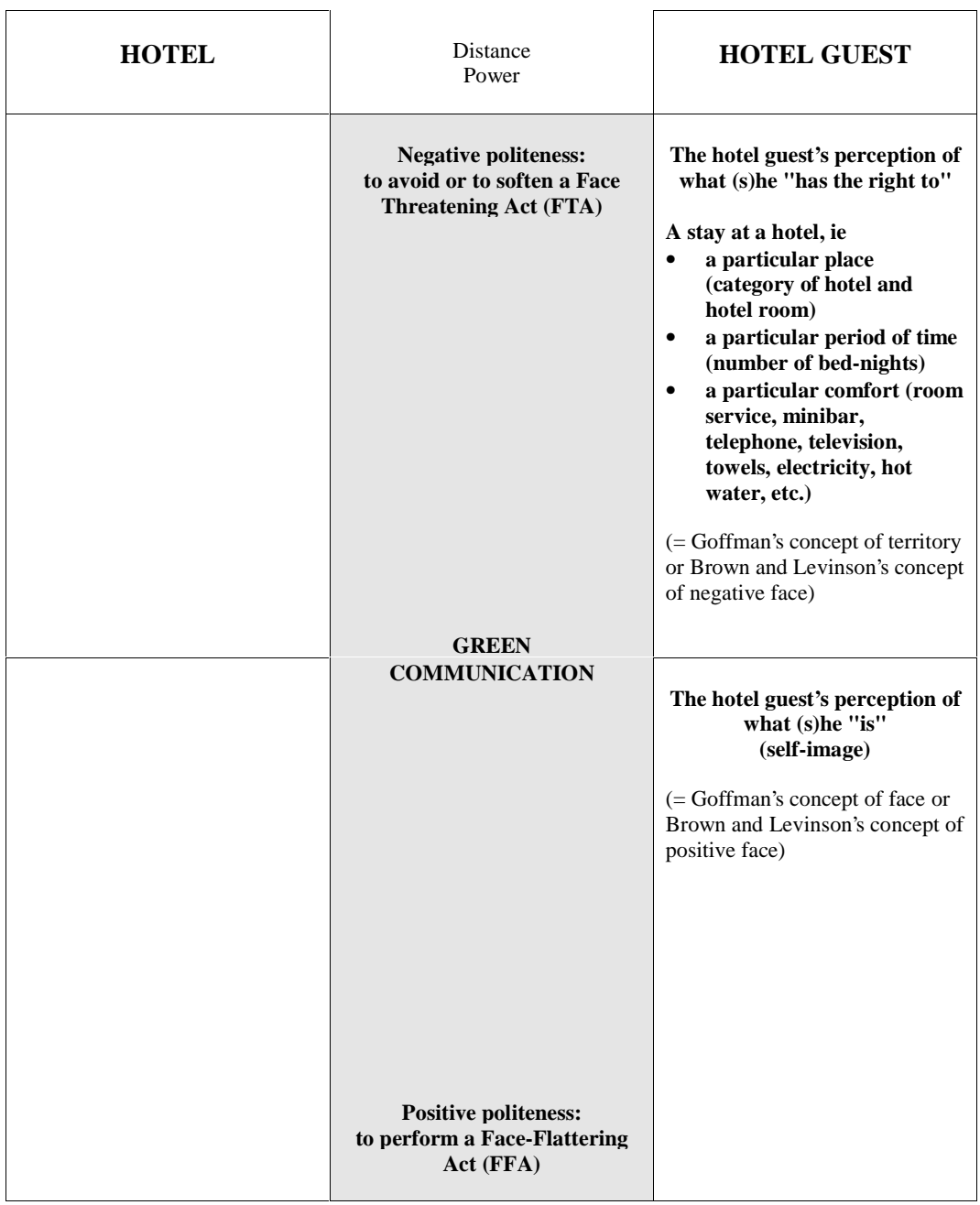


Besides, the hotels themselves contribute to the strenghtening of the hotel guests' idea of the hotel as a fixed territory. In Sweden, the First Hotels market themselves under the slogan "Your second home is First", and in a special advertising supplement to the SAS inflight magazine Scanorama, the Scandic Hotels present themselves as "the Scandinavian home away from home" (Pethrus 2000).

In order to avoid that the green cards and their requests for using the towels once more can be perceived as a threat by the hotel guests, the hotels employ different positive and negative politeness strategies some of which we will list below. Among the positive receiver-oriented politeness strategies the following strategies are worth mentioning:

1) Addressing the hotel guest as an important actor

Reducing the volume of cleaning agents used is one way of helping to conserve nature and the environment. As a guest you can make a difference (Denmark)

You can help us to protect the environment (Denmark)

Please help us save the environment (Sweden)

With your decision to use the towels once again, you contribute to a cleaner and better environment (Denmark).

2) Staging the hotel guest as an actor who already possesses a certain knowledge

It is a well-known fact that every day an enormous amount of laundry detergent is used to launder the hotel towels used just one time (Denmark).

3) Thanking the hotel guest

Thank you! (Denmark)

Among the negative receiver-oriented politeness strategies we would like to mention the following strategies introducing the distinction made by Kerbrat-Orecchioni between replacing expressions (the replacement of a direct wording with a more indirect or "soft" wording) and accompanying expressions (wordings that "soften" a potential threat):

A. Replacing expressions

1) Indirect speech acts

The decision is your's (sic!) (Denmark).

Please decide for yourself (Finland).

Make your own decision (Slovenia). 


\section{2) Use of certain personal pronouns}

De (Vous) instead of $d u(t u)$ (Denmark)

B. Accompanying expressions

1) Specific formulas

Dear guest (Denmark)

Please (Denmark)

2) Disarming expressions

At your disposal are fluffy, clean towels - use as many as you like. But [...] (Denmark)

Is is our pleasure to provide you with fresh towels whenever you wish. Sometimes you will find it not necessary (Finland).

Sie sollen flauschige, saubere Handtücher vorfinden, so viel wie Sie benötigen! Können Sie sich aber vorstellen [...] (Denmark)

Of course you are entitled to receive the full service we have promised you. However [...] (Austria)

\section{3) Diminishing expressions}

Umweltschutz fängt im kleinen an. Wie? Ganz einfach. Indem Sie Ihre Frottierwäsche eventuell auch 2 mal verwenden (Germany).

Nur ein Beispiel: Ein Handtuch vielleicht öfter als nur einmal verwenden (Austria).

Some of these positive or negative politeness strategies also appear in some of the green hotel brochures analysed in Section 5. In the brochure prepared by the Scandic Hotels entitled „The EcoLogical choice - Can you think of a nicer way to care for the environment?" , we find the following two sequences:

As a guest at Scandic, you will not notice any real difference. You will find the same comfortable beds and be able to enjoy the big breakfast buffet with the same appetite. We want to make your stay at Scandic the nicest way to care for the environment imaginable.

And, remember, we never rest on environmental laurels. Something worth thinking about when you relax at Scandic. 


\section{Conclusion}

In this article, we hope to have demonstrated how green hotels in Denmark make use of new text genres and a new rhetoric in their environmental communication. Of greatest interest is, in our opinion, how the hotels try to get round the paradoxes of green marketing within the hotel and tourism industries by means of specific rhetorical strategies. How is it possible to satisfy the hotel guests in their traditional expectations of a certain luxury and at the same time request moderation to save natural resources? As a minimum, the guest must be allowed to decide themselves whether they want to behave in a environmentally-friendly way or not, without being admonishing. But it is, of course, not only a question of changing the expectations and the behavior of the hotel guests, it is also important to create a strong positive image as an ecologically responsible company. Here too, we hope to have demonstrated how the green hotels can create this type of image by communicating in green ways. Whether the green hotels are actually succeeding in persuading their guests about their ,greenness“, is a question that can only be answered by combining the rhetorical analysis with a reception analysis. However, that not all guests are seduced by the environmental rhetoric of green hotels is exemplified by another quotation from David Lodge's Therapy. At the end of the novel, the sit-com writer and Maureen, a woman he has met previously, arrive at Santiago de Compostela in Spain where they take rooms at a five-star hotel, the Hostal de los Reyes Catolicos. Relieved, the sit-com writer immediately ascertains:

„The Hostal is laid out in four exquisite quadrangles, with cloisters, flowerbeds and fountains, each dedicated to one of the evangelists. Our room was off Matthew. It was large and luxurious, the single beds the size of small doubles. Samantha would have loved it. There were sixteen fluffy white towels of different sizes in the marble-lined bathroom, and no nonsense about getting a red card if you wanted them changed" (Lodge 1995: 313). 


\section{References}

Aristoteles: Retorik. Translated into Danish and introduced by Thure Hastrup. Copenhagen: Museum Tusculanum Editions.

Banerjee, S., Gulas, C.S. \& Iyer, E. (1995). Shades of Green: A Multidimensional Analysis of Environmental Advertising. In Journal of Advertising 24 (2). 21-31.

Beck, U. (1989). Risikogesellschaft. Überlebensfragen, Sozialstruktur und ökologische Aufklärung. In Aus Politik und Zeitgeschichte B (36). 3-13.

Brown, P. \& Levinson, S. (1978): Politeness. Some Universals in Language Usage. Cambridge: Cambridge University Press. Second edition 1987.

Brown, S. (1999). Postmodernism: The End of Marketing? In Brownlie, D., Saren, M., Wensley, R. \& Whittington, R. (eds.). Rethinking Marketing: Towards Critical Marketing Accountings. London: Sage.

Carlson, L., Grove, S.J. \& Kangun, H. (1993). A Content Analysis of Environmental Advertising Claims: A Matrix Method. In Journal of Advertising 22 (3). 227-39.

DeLuca, K.M. (1999). Image Politics. The New Rhetoric of Environmental Activism. New York: The Guilford Press.

Diamantis, D. \& Ladkin, A. (1999). 'Green' Strategies' in the Tourism and Hospitality Industries. In Vellas, F. \& Bécherel, L. (eds.). The International Marketing of Travel and Tourism. London: MacMillan Press.

Dowling, G.R. (1986). Managing Your Corporate Image. In Industrial Marketing Management 15. 109-115.

Easterling, D., Kenworthy, A., Nemzoff, R. \& College, B. (1996). The Greening of Advertising: A Twenty-five Year Look at Environmental Advertising. In Journal of Marketing - Theory and Practice. 4 (1). 20-34.

Frandsen, F. \& Johansen, W. (2001). Pour un environnement propre. Genre, politesse et argumentation dans la communication verte des hôtels. In LSP and Professional Communication 1 (1). 37-54.

Fuller, D.A. (1999). Sustainable Marketing. Managerial-Ecological Issues. London: Sage Publications.

Goffman, E. (1972). Relations in Public: Microstudies of the Public Order. New York: Harper \& Row.

Harré, R., Brockmeier, J. \& Mühlhäusler, P. (1999). Greenspeak. A Study of Environmental Discourse. London: Sage Publications.

Harrison, E.B. (1994). Going Green: How to Communicate Your Company's Environmental Commitment. Homewood, IL: Business One Irwin.

Herndl, C.G. \& Brown, S.C. (1996). Green Culture. Environmental Rhetoric in Contemporary America. Madison: The University of Wisconsin Press.

Jakobsen, P.E. (1998). Trends til tiden! En bog om trendforskning, tidstilpasning og produktudvikling. Herning: p.e.j. gruppen. 
Kerbrat-Orecchioni, C. (1992). Les interactions verbales II. Paris: Armand Colin.

Kerbrat-Orecchioni, C. (1996). La conversation. Paris: Le Seuil.

Killingsworth, M. \& Palmer, J.S. (1992). Ecospeak. Rhetoric and Environmental Politics in America. Carbondale and Edwardsville: Southern Illinois University Press.

Lemcke, E. (1999). Økologisk virksomhedskultur - moralsk intuition. In Ledelse i dag 33.

Livesey, S. (1999). McDonald's and the Environmental Defense Fund: A Case Study of a Green Alliance. In The Journal of Business Communication 36 (1). 5-39.

Livesey, S. (2001). Eco-Identity as Discursive Struggle: Royal Dutch/Shell, Brent Spar, and Nigeria. In Journal of Business Communication 38 (1). 58-91.

Lodge, D. (1995). Therapy. London: Martin Secker \& Warburg. Paperback version 1996.

Ogden, C.K. \& Richards, I.A. (1923). The Meaning of Meaning. A Study of the Influence of Language upon Thought and the Science of Symbolism. London: ARK Edition (paperback version 1985).

Ottman, J.A. (1998). Green Marketing. Opportunity for Innovation. Chicago: NTC Business Books.

Pethrus, D-M. (2000). The Scandinavian home away from home (Scandic Hotels - Special advertising supplement). In Scanorama. The takeaway inflight magazine of SAS (March).

Rastier, F. (1989). Sens et textualité. Paris: Hachette.

Riel, C. van (1995). Principles of Corporate Communication. London: Prentice Hall.

$<$ dengroennenoegle.dk>

$<$ www.bestwestern.dk $>$

$<$ www.esf.edu/ecn>

$<$ www.greenglobe21.com> 
